\title{
BACTERIOLOGICAL STUDY ON STAPHYLOCOCCAL BOVINE CLINICAL MASTITIS WITH REFERENCE TO METHICILLIN-RESISTANT STAPH. AUREUS (MRSA)
}

SAYED, S.M.

Animal Health Research Institute, Assiut Regional Laboratory

Email:smhamuda@yahoo.com

\begin{tabular}{|c|c|}
\hline & ABSTRACT \\
\hline Received at: $8 / 12 / 2013$ & $\begin{array}{l}\text { This descriptive study was done on } 101 \text { milk samples obtained from clinically } \\
\text { mastitic dairy cows in Assiut Governorate, Egypt. Staphylococcus aureus }(S \text {. } \\
\text { aureus) was the main causative agent of clinical mastitis ( } 34.65 \%) \text { followed by } S \text {. } \\
\text { saprophyticus (10.89\%), S. intermedius and S. epidermidis }(8.91 \% \text {, for each). The } \\
\text { other causative agents (non Staph. Spp.) were identified. Sensitivity test of } S \text {. } \\
\text { aureus isolates was performed against } 11 \text { antimicrobial agents, where found that } 21\end{array}$ \\
\hline Accepted: 28/12/2013 & $\begin{array}{l}\text { S. aureus strains ( } 60 \%) \text { were methicillin resistant } S \text {. aureus (MRSA). Ten MRSA } \\
\text { strains were subjected for: I- slime-producing factor on Congo Red Agar (CRA) } \\
\text { plates phenotypically, as } 6 \text { isolates }(60 \%) \text { were positive for slime production. II- } \\
\text { PCR which was optimized targeting } m e c A \text {, icaA and icaD genes, where } 5 \text { isolates } \\
(50 \%) \text { were positive for } m e c A \text { gene. Six isolates }(60 \%) \text { and } 8 \text { isolates }(80 \%) \text { were } \\
\text { positive for } i c a A \text { and } i c a D \text { genes, respectively. Five strains }(50 \%) \text { were positive for } \\
\text { both } i c a A \text { and } i c a D \text { genes. Also } 3 \text { strains }(30 \%) \text { were positive for all mecA, icaA } \\
\text { and } i c a D \text { genes. Conclusion, it was concluded that bovine staphylococcal mastitis } \\
\text { was the most predominant issue where } S \text {. aureus was the main cause. Detection of } \\
\text { mecA gene in } S \text {. aureus isolates indicating that several cases suffering from } S \text {. } \\
\text { aureus mastitis have an MRSA problem. Genotypic determination of mec } A \text { gene } \\
\text { proved the most reliable method for detection of methicillin-resistant } S \text {. aureus. The } \\
\text { present work paid an attention to the } 3 \text { MRSA strains ( }(30 \%) \text { were positive to all } \\
\text { tested genes rather than slime production as the worst isolated strains all over this } \\
\text { study (multidrug resistant, slime producing as well as carrying mecA, icaA and icaD } \\
\text { genes). In vitro Enrofloxacin, Gentamicin and Doxycycline the most effective drugs } \\
\text { for Staph. spp. clinical mastitis and should be recommended for treatment of such } \\
\text { cases of bovine mastitis. }\end{array}$ \\
\hline
\end{tabular}

Keywords: Cows, clinical mastitis, methicillin-resistant Staphylococcus aureus, mecA, icaA, icaD, slime factor.

\section{INTRODUCTION}

Mastitis is one of the major challenges of the dairy industry. Staphylococcus aureus (S. aureus) is one of the most important pathogens causing mastitis in dairy cattle (Moon et al., 2007; Nam et al., 2011). Methicillin resistant Staphylococcus aureus (MRSA) has been recovered from dairy cattle in Korea (Moon et al., 2007; Nam et al., 2011 and Lim et al., 2013); Turkey (Ciftci et al., 2009); Netherland (Tavakol et al., 2012); Iran (Ahmady and Kazemi, 2013) and Uganda (Kateete et al., 2013). Several efforts to remove this pathogen from farms are hampered by some factors, where one of these factors is antibiotic resistance. One of the major mechanisms of resistance to $\beta$-lactam antibiotics is $\beta$-lactamase producing by staphylococci. This enzyme hydrolyzes the $\beta$ - lactam ring and causes inactivation of $\beta$ lactams. In the early 1950s, it has been aware of the effectiveness of penicillin in treatment of $S$. aureus infections because of $\beta$-lactamase producing plasmids. In 1959, methicillin, synthetic, penicillinase -resistant penicillin, was introduced and solved problems in clinical practice, for a time. However, by 1960, S. aureus strains were found to be resistant to the new semisynthetic $\beta$-lactams (methicillin, oxacillin, flucloxacillin), and became known as methicillin-resistant $S$. aureus (MRSA). This type of resistance was termed "intrinsic resistance" because it was not due to destruction of the antibiotic by $\beta$ lactamase (Chambers, 1997). Methicillin resistance in $S$. aureus is mediated by the production of an altered penicillin-binding protein (PBP2a), a transpeptidase. mecA encodes this enzyme involved in cell wall peptidoglycan synthesis. Unlike conventional PBPs of $S$. aureus, PBP2a does not bind to $\beta$-lactam antibiotics with high affinity (Hiramatsu et al., 2002).

It is considered that the first step in mastitis progress is adhesion of $S$. aureus to mammary epithelial cells and slime factor plays an important role for adhesion 
and colonization (Vasudevan et al., 2003). Production of slime factor also plays an important role in antibiotic resistance and it has been reported that slime producing strains are more resistant to antibiotics than non-slime producing strains (Amorena et al., 1999). Intercellular adhesion is encoded in the ica locus containing icaA, icaB, icaC, icaD genes in $S$. aureus strains (Yazdani et al., 2006). icaA gene encodes $\mathrm{N}$-acetylglucosaminyl transferase, further, icaD plays an important role in expression of this enzyme. icaA and icaD were found to be in high prevalence among $S$. aureus mastitis isolates and this finding confirms that ica locus has a potential role as a virulence factor in the pathogenesis of mastitis in ruminants (Vasudevan et al., 2003).

This study was undertaken to determine the bovine mastitis Staph. Spp., their resistance to antimicrobial agents approved for its control and to determine the methicillin resistance and slime factor production of $S$. aureus in bovine mastitis phenotypically and genotypically for mecA, icaA and icaD genes.

\section{MATERIALS and METHODS}

\section{Milk samples:}

A total of 101 milk samples were collected from 101 cows, at various private farms in Assiut, Egypt, showing clinical signs of mastitis. All samples were taken under aseptic conditions and transferred in ice box to laboratory as soon as possible.

\section{Isolation and identification of bacterial isolates:}

Amount of $0.01 \mathrm{ml}$ of each milk samples was cultured on blood agar with 5\% sheep blood, Mannitol salt agar (BBL), Baird-Parker medium (Oxoid) and MacConkey agar (Biomark Lab. India) which incubated at $37^{\circ} \mathrm{c}$ for $48 \mathrm{~h}$. The suspected colonies were identified: morphologically, by Gram's stain and biochemically confirmed by using catalase activity, coagulase test as well as Novobiocin $(5 \mu \mathrm{g})$ and polymixin- $\beta$ sulphate $(300 \mathrm{U})$ sensitivity tests, according to Quinn et al. (2004).

\section{Phenotypic detection of methicillin resistance:}

Disc diffusion sensitivity testing was performed according to the Kirby-Bauer method, as described in the guidelines of the National Committee for Laboratory Standards (NCCLS, 2000), using discs
(Bioanalyse-Turkey) containing Oxacillin (OX) $1 \mu \mathrm{g}$, Ampicilin (AM) $10 \mu \mathrm{g}$, Cefotaxime (CTX) $30 \mu \mathrm{g}$, Cloxacillin (CX) $1 \mu \mathrm{g}$, Doxycycline (DO) $30 \mu \mathrm{g}$, Enrofloxacin (ENR) $5 \mu \mathrm{g}$, Gentamicin (CN) $10 \mu \mathrm{g}$, Lincomycin (L) $2 \mu \mathrm{g}$, Oxytetracycline (T) $30 \mu \mathrm{g}$, Penicillin (P) $10 \mu$ and Trimethoprim Sulflamethaxzole (SXT) $25 \mu \mathrm{g}$. For Oxacillin susceptibility determinations, inhibition zones around the disc were measured after 24 and $48 \mathrm{~h}$ using the following breakpoints: susceptible $(\mathrm{S}) \geq 18 \mathrm{~mm}$; resistance (R) $\leq 17 \mathrm{~mm}$ (Quinn et al., 2004).

\section{Slime production assay:}

Slime production assay was performed by cultivation of ten $S$. aureus strains, which were methicillin resistant by phenotypic test, on Congo Red Agar (CRA) plates containing $0.8 \mathrm{~g}$ of Congo Red dye, 21 g Mueller-Hinton broth, $15 \mathrm{~g}$ granulated agar and 36 g sucrose per Liter distilled water. Strains were inoculated on CRA plates and incubated for 24-72 h at $37^{\circ} \mathrm{C}$. Slime producing strains and non-slime producing strains constitutes rough black colonies and red colonies on CRA, respectively (Yazdani et al., 2006).

PCR for detection of mecA, icaA and icaD genes: Detection of mecA, icaA and icaD genes was performed on those ten $S$. aureus isolates, which were methicillin resistant by phenotypic test, as follows:

I- DNA extraction: DNA extraction from samples was performed using the QIAamp DNA Mini kit (Qiagen, Germany, GmbH) with modifications from the manufacturer's recommendations. Briefly, $200 \mu \mathrm{l}$ of the sample suspension was incubated with $10 \mu \mathrm{l}$ of proteinase $\mathrm{K}$ and $200 \mu \mathrm{l}$ of lysis buffer at $56^{\mathrm{O}} \mathrm{C}$ for 10 min. After incubation, $200 \mu \mathrm{l}$ of $100 \%$ ethanol was added to the lysate. The sample was then washed and centrifuged following the manufacturer's recommendations. Nucleic acid was eluted with 100 $\mu \mathrm{l}$ of elution buffer provided in the kit.

II- Oligonucleotide Primers: Primers encoding for $m e c A$, icaA and icaD genes were supplied from (Metabion, Germany) are listed in Table (1). 
$\underline{\text { Assiut Vet. Med. J. Vol. } 60 \text { No. } 140 \text { January } 2014}$

Table 1: Primers sequences, target genes, amplicon sizes.

\begin{tabular}{|c|c|c|c|c|}
\hline Primer & $\begin{array}{l}\text { Target } \\
\text { gene }\end{array}$ & $\begin{array}{l}\text { Primer sequence } \\
\qquad\left(5^{\prime}-3^{\prime}\right)\end{array}$ & $\begin{array}{c}\text { Length of } \\
\text { amplified } \\
\text { product (bp) }\end{array}$ & Reference \\
\hline mec $A-1$ & \multirow{2}{*}{ mecA } & $\begin{array}{l}\text { GTA GAA ATG ACT GAA CGT CCG ATA } \\
\text { A }\end{array}$ & \multirow{2}{*}{$310 \mathrm{bp}$} & \multirow{2}{*}{ McClure et al. (2006) } \\
\hline mec $A-2$ & & CCA ATT CCA CAT TGT TTC GGT CTA A & & \\
\hline IcaA- AF & \multirow{2}{*}{ IcaA } & CCT AAC TAA CGA AAG GTA G & \multirow{2}{*}{$1315 \mathrm{bp}$} & \multirow{4}{*}{ Ciftci et al. (2009) } \\
\hline IcaA- AR & & AAG ATA TAG CGA TAA GTG C & & \\
\hline IcaD- DF & \multirow{2}{*}{$I c a D$} & AAA CGT AAG AGA GGT GG & \multirow{2}{*}{$381 \mathrm{bp}$} & \\
\hline$I c a D-D R$ & & GGC AAT ATG ATC AAG ATA & & \\
\hline
\end{tabular}

III- PCR amplification: Primers were utilized in a 25- $\mu$ l reaction containing $12.5 \mu \mathrm{l}$ of Emerald Amp Max PCR Master Mix (Takara, Japan), $1 \mu$ l of each primer of $20 \mathrm{pmol}$ concentration, $4.5 \mu \mathrm{l}$ of water, and $6 \mu \mathrm{l}$ of template. The reaction was performed in a Biometra thermal cycler. For mecA gene PCR, a primary denaturation step was done at $95^{\circ} \mathrm{C}$ for $5 \mathrm{~min}$, followed by 35 cycles of $95^{\circ} \mathrm{C}$ for $45 \mathrm{sec}$, $50^{\circ} \mathrm{C}$ for 45 sec. and $72^{\circ} \mathrm{C}$ for $45 \mathrm{sec}$. A final extension step was done at $72^{\circ} \mathrm{C}$ for $10 \mathrm{~min}$, according to McClure et al. (2006). However for the $i c a A$ and $i c a D$ genes, the cycles consisted of $95^{\circ} \mathrm{C}$ for $1 \mathrm{~min}, 49^{\circ} \mathrm{C}$ for $1 \mathrm{~min}$ and $72^{\circ} \mathrm{C}$ for $1 \mathrm{~min}$, according to Ciftci et al. (2009).
IV-Analysis of the PCR Products: The products of PCR were separated by electrophoresis on $1.5 \%$ agarose gel (Applichem, Germany, GmbH) in $1 \mathrm{x}$ TBE buffer at room temperature using gradients of $5 \mathrm{~V} / \mathrm{cm}$. For gel analysis, $15 \mu \mathrm{l}$ of the products was loaded in each gel slot. A 100 bp DNA Ladder (Qiagen, Germany, GmbH) and 100 bp plus DNA Ladder (Fermentas, Cat.No. SM 0323) were used to determine the fragment sizes. The gel was photographed by a gel documentation system (Alpha Innotech, Biometra) and the data was analyzed through computer software.

\section{RESULTS}

Table 2: Isolated micro-organisms from mastitic milk samples.

\begin{tabular}{|c|c|c|c|}
\hline & Isolates & No. & $\%$ \\
\hline \multirow{6}{*}{ Staph. spp } & Coagulase + ve Staph. spp. & & \\
\hline & 1- S. aureus & 35 & 34.65 \\
\hline & 2- S. intermedius & 9 & 8.91 \\
\hline & Coagulase -ve Staph. spp. & & \\
\hline & 1- S. saprophyticus & 11 & 10.89 \\
\hline & 2- S. epidermidis & 9 & 8.91 \\
\hline \multirow{4}{*}{ Non Staph. spp } & Gram -ve bacilli & 32 & 31.68 \\
\hline & Corynebacterium spp. & 4 & 3.96 \\
\hline & Strept. Pyogenes & 1 & 0.99 \\
\hline & Total & 101 & 100 \\
\hline
\end{tabular}


Assiut Vet. Med. J. Vol. 60 No. 140 January 2014

Table 3: In vitro antimicrobial susceptibility test of isolated Staph. spp. From bovine clinical mastitis according to the agar disc diffusion method.

\begin{tabular}{|c|c|c|c|c|c|c|c|c|c|c|}
\hline \multirow{2}{*}{$\begin{array}{l}\text { Antimicrobial } \\
\text { Agents }\end{array}$} & \multicolumn{2}{|c|}{ S. aureus $(\mathrm{n} .=35)$} & \multicolumn{2}{|c|}{$\begin{array}{l}\text { S. intermedius } \\
\qquad(\mathrm{n} .=9)\end{array}$} & \multicolumn{2}{|c|}{$\begin{array}{c}\text { S. saprophyticus } \\
(\mathrm{n} .=11)\end{array}$} & \multicolumn{2}{|c|}{ S. epidermidis $(\mathrm{n} .=9)$} & \multicolumn{2}{|c|}{ Total $(\mathrm{n} .=64)$} \\
\hline & Sensitive & Resistant & Sensitive & Resistant & Sensitive & Resistant & Sensitive & Resistant & Sensitive & Resistant \\
\hline Oxacillin & $\begin{array}{c}14 \\
(40 \%)\end{array}$ & $\begin{array}{c}21 \\
(60 \%)\end{array}$ & $\begin{array}{c}6 \\
(66.67 \%)\end{array}$ & $\begin{array}{c}3 \\
(33.33 \%)\end{array}$ & $\begin{array}{c}4 \\
(36.36 \%)\end{array}$ & $\begin{array}{c}7 \\
(63.64 \%)\end{array}$ & $\begin{array}{c}5 \\
(55.56 \%)\end{array}$ & $\begin{array}{c}4 \\
(44.44 \%)\end{array}$ & $\begin{array}{c}29 \\
(45.31 \%)\end{array}$ & $\begin{array}{c}35 \\
(54.69 \%)\end{array}$ \\
\hline Enrofloxacin & $\begin{array}{c}35 \\
(100 \%)\end{array}$ & $\begin{array}{c}0 \\
(0 \%)\end{array}$ & $\begin{array}{c}9 \\
(100 \%)\end{array}$ & $\begin{array}{c}0 \\
(0 \%)\end{array}$ & $\begin{array}{c}11 \\
(100 \%)\end{array}$ & $\begin{array}{c}0 \\
(0 \%)\end{array}$ & $\begin{array}{c}9 \\
(100 \%)\end{array}$ & $\begin{array}{c}0 \\
(0 \%)\end{array}$ & $\begin{array}{c}64 \\
(100 \%)\end{array}$ & $\begin{array}{c}0 \\
(0 \%)\end{array}$ \\
\hline Gentamicin & $\begin{array}{c}35 \\
(100 \%)\end{array}$ & $\begin{array}{c}0 \\
(0 \%)\end{array}$ & $\begin{array}{c}9 \\
(100 \%)\end{array}$ & $\begin{array}{c}0 \\
(0 \%)\end{array}$ & $\begin{array}{c}11 \\
(100 \%)\end{array}$ & $\begin{array}{c}0 \\
(0 \%)\end{array}$ & $\begin{array}{c}9 \\
(100 \%)\end{array}$ & $\begin{array}{c}0 \\
(0 \%)\end{array}$ & $\begin{array}{c}64 \\
(100 \%)\end{array}$ & $\begin{array}{c}0 \\
(0 \%)\end{array}$ \\
\hline Doxycycline & $\begin{array}{c}32 \\
(91.43 \%)\end{array}$ & $\begin{array}{c}3 \\
(8.57 \%)\end{array}$ & $\begin{array}{c}9 \\
(100 \%)\end{array}$ & $\begin{array}{c}0 \\
(0 \%)\end{array}$ & $\begin{array}{c}10 \\
(90.91 \%)\end{array}$ & $\begin{array}{c}1 \\
(9.09 \%)\end{array}$ & $\begin{array}{c}9 \\
(100 \%)\end{array}$ & $\begin{array}{c}0 \\
(0 \%)\end{array}$ & $\begin{array}{c}60 \\
(93.75 \%)\end{array}$ & $\begin{array}{c}4 \\
(6.25 \%)\end{array}$ \\
\hline $\begin{array}{l}\text { Trimethoprim - } \\
\text { Sulflamethaxzole }\end{array}$ & $\begin{array}{c}18 \\
(51.43 \%)\end{array}$ & $\begin{array}{c}17 \\
(48.57 \%)\end{array}$ & $\begin{array}{c}7 \\
(77.77 \%)\end{array}$ & $\begin{array}{c}2 \\
(22.22 \%)\end{array}$ & $\begin{array}{c}5 \\
(45.45 \%)\end{array}$ & $\begin{array}{c}6 \\
(54.55 \%)\end{array}$ & $\begin{array}{c}7 \\
(77.77 \%)\end{array}$ & $\begin{array}{c}2 \\
(22.22 \%)\end{array}$ & $\begin{array}{c}37 \\
(57.81 \%)\end{array}$ & $\begin{array}{c}27 \\
(42.18 \%)\end{array}$ \\
\hline Oxytetracycline & $\begin{array}{c}18 \\
(51.43 \%)\end{array}$ & $\begin{array}{c}17 \\
(48.57 \%)\end{array}$ & $\begin{array}{c}6 \\
(66.67 \%)\end{array}$ & $\begin{array}{c}3 \\
(33.33 \%)\end{array}$ & $\begin{array}{c}7 \\
(63.64 \%)\end{array}$ & $\begin{array}{c}4 \\
(36.36 \%)\end{array}$ & $\begin{array}{c}6 \\
(66.67 \%)\end{array}$ & $\begin{array}{c}3 \\
(33.33 \%)\end{array}$ & $\begin{array}{c}37 \\
(57.81 \%)\end{array}$ & $\begin{array}{c}27 \\
(42.18 \%)\end{array}$ \\
\hline Penicillin & $\begin{array}{c}15 \\
(42.86 \%)\end{array}$ & $\begin{array}{c}20 \\
(57.14 \%)\end{array}$ & $\begin{array}{c}5 \\
(55.56 \%)\end{array}$ & $\begin{array}{c}4 \\
(44.45 \%)\end{array}$ & $\begin{array}{c}7 \\
(63.64 \%)\end{array}$ & $\begin{array}{c}4 \\
(36.36 \%)\end{array}$ & $\begin{array}{c}5 \\
(55.56 \%)\end{array}$ & $\begin{array}{c}4 \\
(44.45 \%)\end{array}$ & $\begin{array}{c}32 \\
(50 \%)\end{array}$ & $\begin{array}{c}32 \\
(50 \%)\end{array}$ \\
\hline Ampicilin & $\begin{array}{c}13 \\
(37.43 \%)\end{array}$ & $\begin{array}{c}22 \\
(68.86 \%)\end{array}$ & $\begin{array}{c}7 \\
(77.77 \%)\end{array}$ & $\begin{array}{c}2 \\
(22.22 \%)\end{array}$ & $\begin{array}{c}7 \\
(63.64 \%)\end{array}$ & $\begin{array}{c}4 \\
(36.36 \%)\end{array}$ & $\begin{array}{c}3 \\
(33.33 \%)\end{array}$ & $\begin{array}{c}6 \\
(66.67 \%)\end{array}$ & $\begin{array}{c}30 \\
(46.88)\end{array}$ & $\begin{array}{c}34 \\
(53.12 \%)\end{array}$ \\
\hline Cloxacillin & $\begin{array}{c}14 \\
(40 \%)\end{array}$ & $\begin{array}{c}21 \\
(60 \%)\end{array}$ & $\begin{array}{c}6 \\
(66.67 \%)\end{array}$ & $\begin{array}{c}3 \\
(33.33 \%)\end{array}$ & $\begin{array}{c}4 \\
(36.36 \%)\end{array}$ & $\begin{array}{c}7 \\
(63.64 \%)\end{array}$ & $\begin{array}{c}5 \\
(55.56 \%)\end{array}$ & $\begin{array}{c}4 \\
44.45 \%)\end{array}$ & $\begin{array}{c}29 \\
(45.31 \%)\end{array}$ & $\begin{array}{c}35 \\
(54.69 \%)\end{array}$ \\
\hline Cefotaxime & $\begin{array}{c}4 \\
(11.43 \%)\end{array}$ & $\begin{array}{c}31 \\
(88.57 \%)\end{array}$ & $\begin{array}{c}3 \\
(33.33 \%)\end{array}$ & $\begin{array}{c}6 \\
(66.67 \%)\end{array}$ & $\begin{array}{c}1 \\
(9.09 \%)\end{array}$ & $\begin{array}{c}10 \\
(90.915 \%)\end{array}$ & $\begin{array}{c}0 \\
(0 \%)\end{array}$ & $\begin{array}{c}9 \\
(100 \%)\end{array}$ & $\begin{array}{c}8 \\
(12.5 \%)\end{array}$ & $\begin{array}{c}56 \\
(87.5 \%)\end{array}$ \\
\hline Lincomycin & $\begin{array}{c}3 \\
(8.57 \%)\end{array}$ & $\begin{array}{c}32 \\
(91.43 \%)\end{array}$ & $\begin{array}{c}3 \\
(33.33 \%)\end{array}$ & $\begin{array}{c}6 \\
(66.67 \%)\end{array}$ & $\begin{array}{c}0 \\
(0 \%)\end{array}$ & $\begin{array}{c}11 \\
(100 \%)\end{array}$ & $\begin{array}{c}0 \\
(0 \%)\end{array}$ & $\begin{array}{c}9 \\
(100 \%)\end{array}$ & $\begin{array}{c}6 \\
(9.38 \%)\end{array}$ & $\begin{array}{c}58 \\
(90.63 \%)\end{array}$ \\
\hline
\end{tabular}

Table 4: Methicillin resistant $S$. aureus strains tested for their phenotypic and genotypic characteristics and slime factor production.

\begin{tabular}{ccccc}
\hline $\begin{array}{c}\text { MRSA } \\
\text { strains }\end{array}$ & $\begin{array}{c}\text { Congo red } \\
\text { agar test }\end{array}$ & mecA & Genes & icaA \\
\cline { 3 - 5 } 1 & $-\mathrm{ve}$ & $-\mathrm{ve}$ & $-\mathrm{ve}$ & $+\mathrm{ve}$ \\
\hline 2 & $-\mathrm{ve}$ & $-\mathrm{ve}$ & $+\mathrm{ve}$ & $+\mathrm{ve}$ \\
\hline 3 & $-\mathrm{ve}$ & $-\mathrm{ve}$ & $-\mathrm{ve}$ & $-\mathrm{ve}$ \\
\hline 4 & $+\mathrm{ve}$ & $-\mathrm{ve}$ & $-\mathrm{ve}$ & $+\mathrm{ve}$ \\
\hline 5 & $+\mathrm{ve}$ & $-\mathrm{ve}$ & $+\mathrm{ve}$ & $+\mathrm{ve}$ \\
\hline 6 & $+\mathrm{ve}$ & $+\mathrm{ve}$ & $+\mathrm{ve}$ & $+\mathrm{ve}$ \\
\hline 7 & $-\mathrm{ve}$ & $+\mathrm{ve}$ & $-\mathrm{ve}$ & $+\mathrm{ve}$ \\
\hline 8 & $+\mathrm{ve}$ & $+\mathrm{ve}$ & $+\mathrm{ve}$ & $+\mathrm{ve}$ \\
\hline 9 & $+\mathrm{ve}$ & $+\mathrm{ve}$ & $+\mathrm{ve}$ & $-\mathrm{ve}$ \\
\hline 10 & $+\mathrm{ve}$ & $+\mathrm{ve}$ & $+\mathrm{ve}$ & \\
\hline
\end{tabular}




\section{Assiut Vet. Med. J. Vol. 60 No. 140 January 2014}

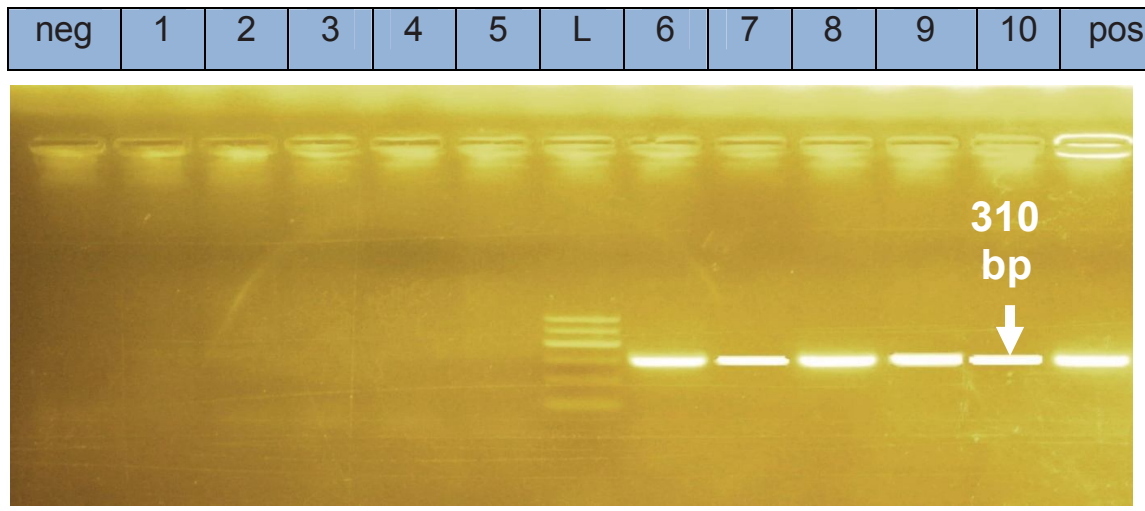

Fig. 1: PCR results for $m e c A$ gene showing amplification of 310 bp. (L): 100 bp ladder (QIAGEN, Gmbh) (100$600 \mathrm{bp}), 1-10$ lanes for the 10 strains respectively.

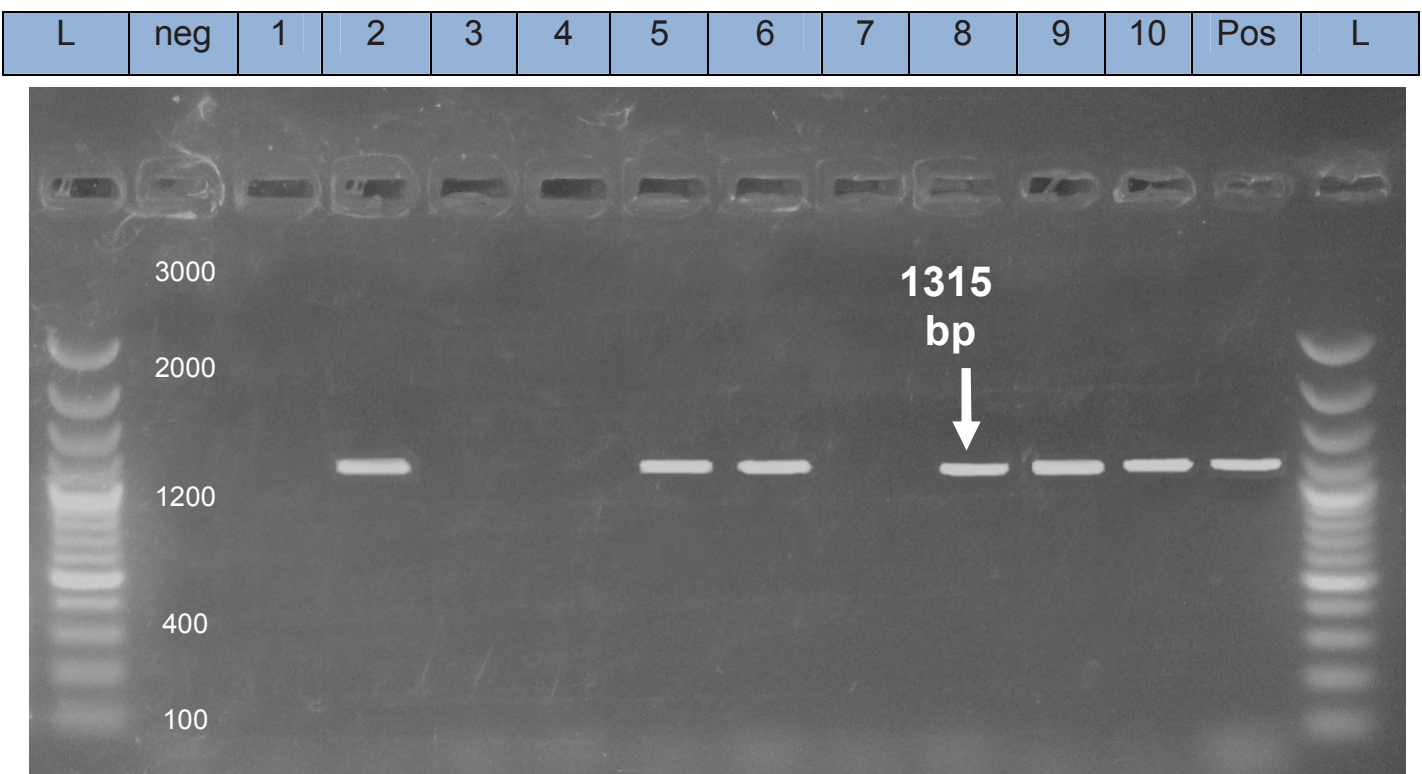

Fig. 2: PCR results for icaA gene showing amplification of 1315 bp. (L): 100 bp plus ladder (Fermentas, Cat. no. SM 0323) (100-3000 bp), 1-10 lanes for the 10 strains respectively.

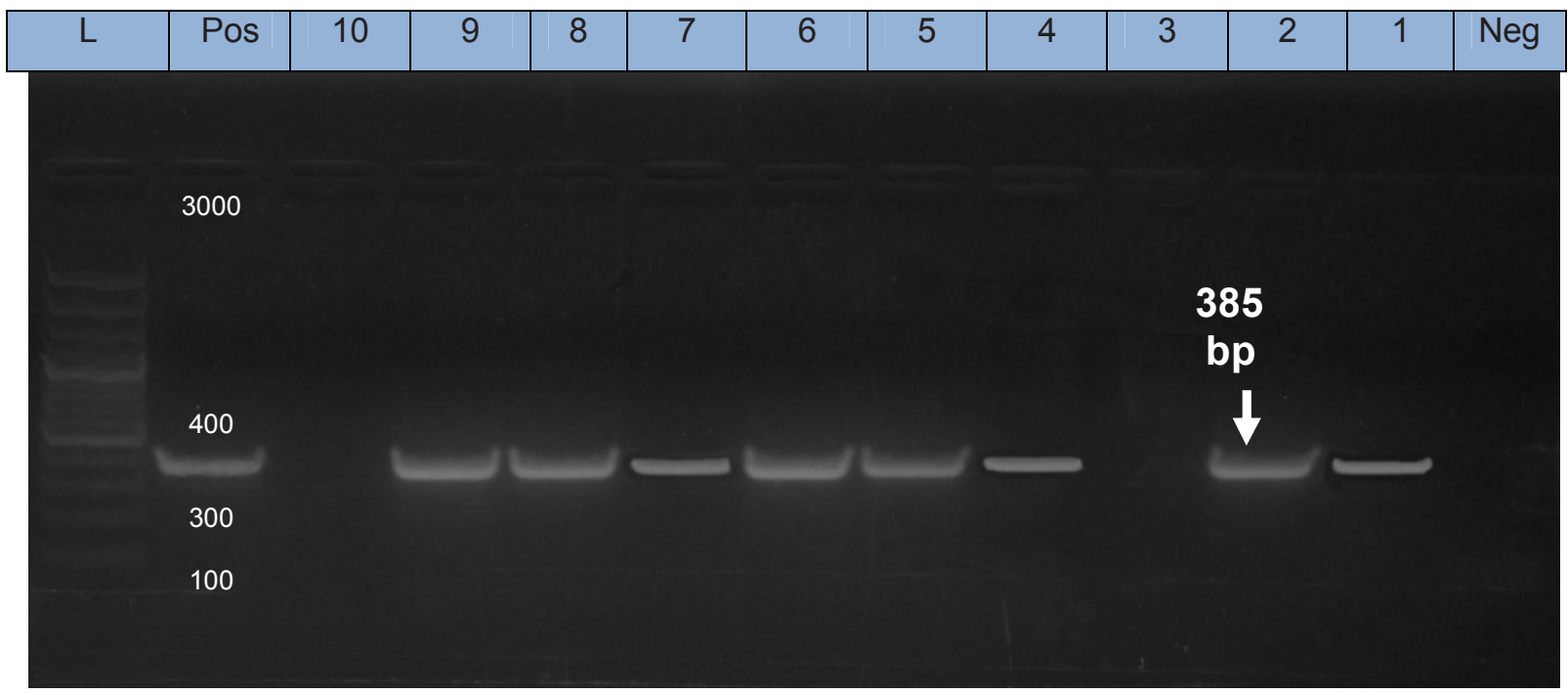

Fig. (3): PCR results for icaD gene showing amplification of 385 bp. (L): 100 bp plus ladder (Fermentas, Cat. no. SM 0323) (100-3000 bp), 1-10 lanes for the 10 strains respectively. 


\section{DISCUSSION}

Mastitis is an important and a persistent infection producing high economies losses due to poor milk quality, reduced milk yield and increased expenditure on treatment especially staphylococcal mastitis (AbdElrahman, 2013) which resembled $63.37 \%$ through the current study and bacteriological examination shows that $S$. aureus was the main causative agent of clinical mastitis in cows (34.65\%), followed by $S$. saprophyticus $(10.89 \%), S$. intermedius and $S$. epidermidis (8.91\%, for each), as shown in Table (2). This result of $S$. aureus in close agreement with previous findings; 30,30 and $36 \%$, by Reddy et al. (2007); Ali et al. (2008) and Haftu et al. (2012), respectively. However, the findings $(71.4 \%)$ of $S$. aureus by Abou-Zaid and El-Sawalhy (1999) are much higher than the present report. The lower prevalence reported by Eman et al. (2006); Moniri et al. (2007) and Sayed \& Mohamed (2008); (21.7; 21.9 and $23.6 \%$, respectively). High prevalence of $S$. aureus points to poor milking hygiene as this pathogen is mainly spread during milking via milkers' hands and towels (Bradley, 2002).

In vitro activities of Staph. spp. against 11 antimicrobial agents are summarized in Table (3). In the present work the highest rate of resistant $S$. aureus exhibited to Lincomycin followed by Cefotaxime, Ampicilin and Penicillin (91.43, 88.57, 68.86 and $57.14 \%$, respectively) and MRSA resembled $60 \%$ of these isolates. The highest rate of sensitivity to Enrofloxacin and Gentamicin followed by Doxycycline (100, 100 and 91.43\%, respectively), Table (3). Abd-Elrahman (2013) found that Enrofloxacin the most effective drugs against $S$. aureus. The highest resistance rate of $S$. aureus against Penicillin (47.6, 47.6, 56.5 and 66\%) was reported by Calvinho et al. (2002); Gianneechini et al. (2002); Arshad et al. (2006) and Nam et al. (2011), respectively. Vanderhaeghen et al. (2010) found an unusual high prevalence of MRSA in Belgian cases of subclinical and clinical S. aureus mastitis in cows. $S$. aureus can adapt rapidly to the selective pressure of antibiotics and this resulted in emergence and spread of MRSA (Deurenberg et al., 2007).

Extracellular polysaccharides, slime factor, are considered to be significant virulence factors for some staphylococci. Slime layer surrounding the $S$. aureus strains help in adherence and colonization of these microorganisms on the mammary gland epithelium. It is reported that slime factor production in $S$. aureus isolates from mastitis cause antibiotic resistance which is due to the decreased diffusion of antibiotics through the biofilm matrix and decreased metabolic activity of bacteria (Amorena et al., 1999 and Yazdani et al., 2006).

In the present study, ten MRSA strains were subjected for slime production on Congo Red Agar
(CRA) plates and PCR study targeting mecA, icaA and icaD genes. Among the tested MRSA strains only five isolates $(50 \%)$ were positive for mecA gene genotypically, Table (4) and Fig. (1). Moon et al. (2007) and Ciftci et al. (2009) detected that 61.9 and $30.7 \%$ of MRSA were positive for mecA gene, respectively. MRSA resistance to methicillin and other ß-lactam antibiotics is caused by the action of mecA gene (Deurenberg et al., 2007). The discrepant results between disc diffusion methods and PCR for detection of methicillin resistance may be due to another resistance mechanism such as hyperproduction of beta-lactamase, also MRSA strains show a heterogeneous character with the level of resistance varying according to the culture conditions and $\beta$-lactam antibiotic being used. Because of this heterogeneous resistance, and time consuming the detection of MRSA by phenotypic methods becomes problematic, Ciftci et al. (2009). However, PCR-based methods have shown to be a rapid and reliable approach for the identification and genotypic characterization of MRSA. Detection of $m e c A$ - based PCR methods has accepted as "gold standard" (Sancak, 2000).

The present work found that six isolates $(60 \%)$ of the tested MRSA strains were slime producing positive on CRA plates in vitro, Table (4). Slime-producing $S$. aureus isolates from different clinical origins such as bovine mastitis (Vasudevan et al., 2003) and (Ciftci et al., 2009), wound infection (Yazdani et al., 2006) and clinical cases (Eftekhar and Dadaei, 2011) has been detected in vitro by using Congo Red Agar plates in percentages of $91.4,37.2,52$ and $53.3 \%$, respectively. Knobloch et al. (2002) have reported that the phenotype on CRA was found to be an unreliable indicator of slime-forming capacity among clinical isolates of $S$. aureus. Therefore, although CRA methods may be easier to perform than a molecular analysis of the genes implicated in biofilm production and could be performed easily in a diagnostic laboratory, it may be a poor method for determining the slime producing capacity of clinical isolates in the diagnostic laboratory (Fitzpatrick et al., 2005).

PCR methods provided a direct evidence of the genetic basis of slime production complementary to the CRA test. The ica locus consists ica $A, D, B, C$ genes. Slime synthesis is controlled by the ica (intercellular adhesion) operon. Coexpression of icaA with $i c a D$ leads to a significant increase in activity and is related to phenotypic expression of the capsular polysaccharide (Arciola et al., 2001). In this study, slime factor production of MRSA isolates were detected by PCR targeting icaA and icaD genes and found that $5(50 \%)$ of the tested MRSA strains were positive for both icaA and icaD genes. Six (60\%) and eight $(80 \%)$ isolates were positive for icaA gene and icaD gene, respectively as shown in Table (4) and Fig. (2 \& 3). Ciftci et al. (2009) reported that 15 
$(25.42 \%)$ out of $59 \mathrm{~S}$. aureus strains were positive for both icaA and icaD genes. Sixteen (27.12\%) and 38 (64.41\%) out of 59 strains were positive for icaA and icaD gene, respectively. Also Eftekhar and Dadaei (2011) found that $75 \%$ of MRSA carried ica operon. The icaAD gene was detected in $32 \%$ of Staphylococcal spp. (Rasha et al., 2012). While it was contrast to Arciola et al. (2001) who have reported that all strains which were positive for icaA gene were also positive for $i c a D$ gene. In addition, Vasudevan et al. (2003) and Yazdani et al. (2006) have reported that all $S$. aureus isolates possessed the ica locus, icaA and icaD genes. icaA and icaD genes were not be together in some isolates may due to some mutations on icaA gene, although coexpression on icaA and icaD is necessary for slime production it was considered that other genes in ica locus play role in controlling slime expression, (Ciftci et al., 2009).

In present study, among four isolates which were negative for slime production on CRA plate in vitro, one isolate was positive for both icaA and icaD genes, two isolates were positive for $i c a D$ gene and the last one was negative for both icaA and icaD genes, Table (4). Ciftci et al. (2009) found among the $37 \mathrm{~S}$. aureus strains which did not produce slime factor on CRA plate in vitro, only $7(18.9 \%)$ strains were positive for both icaA and icaD genes. Who suggests that some environmental conditions or presence of accessory genes can influence the phenotypic behavior on the Congo red agar plate, giving colonies which did not fully express the ica genes.

In this work, six isolates $(60 \%)$ were positive for both methicillin resistance and slime production phenotypically and three strains $(30 \%)$ were positive for all mecA, icaA and icaD genes, Table (4). Only 2 (3.39\%) of 59 S. aureus strains were positive for both methicillin resistance and slime producing, phenotypically, Ciftci et al. (2009).

In conclusion, it was showed that detection of mecA gene in $S$. aureus isolates indicating that several cases suffering from $S$. aureus mastitis have an MRSA problem. Genotypic determination of mecA gene proved the most reliable method for detection of methicillin resistance. The present work paid an attention to the 3 MRSA strains $(30 \%)$ were positive to all tested genes rather than slime production as the worst isolated stains all over this study (multidrug resistant, slime producing as well as carrying $m e c A$, $i c a A$ and icaD genes). In vitro Enrofloxacin, Gentamicin and Doxycycline are the most effective drugs for Staph. spp. clinical mastitis.

\section{REFERENCES}

Abd-Elrahman, A.H. (2013): Mastitis in housed dairy buffaloes: incidence, etiology, clinical finding, antimicrobial sensitivity and different medical treatment against $E$. coli mastitis. Life Science J. 10(1): $532-538$.

Abou-Zaid, A. and El-Sawalhy, A. (1999): Some studies on mastitis in cattle. Alex. J. Vet., 15(1):23-34.

Ahmady, M. and Kazemi, S. (2013): Detection of the enterotoxigenic genes (sei, sej) in Staphylococcus aureus isolates from bovine mastitis milk in the West Azerbaijan of Iran. Comp. Clin. Path., 22(4):649-654.

Ali, L.; Muhammed, G.; Arshad, M.; Saqib, M. and Hassan, I.J. (2008): Bacteriology of mastitis buffaloes in Tehsil Samundri of district Faisalabad. Pakistan Vet. J. 28 (1); 31-33.

Amorena, B.; Gracia, E.; Monzon, M.; Leiva, J.; Oteiza, C.; Perez, M.; Alabart, J.L. and Hernandez-Yago, J. (1999): Antibiotic susceptibility assay for Staphylococcus aureus in biofilms developed in vitro. J. Antimicrob. Chemother., 44: 43-55.

Arciola, C.R.; Baldassarri, L. and Montanaro, L. (2001): Presence of icaA and icaD genes and slime production in a collection of staphylococcal strains from catheter-associated infections. J. Clin. Microbiol., 39 (6): 21512156.

Arshad, M.; Muhammad, G.; Siddique, M.; Ashraf, M. and Khan, H.A. (2006): Staphylococcal mastitis in bovine and some properties of Staphylococcal isolates. Pakistan. Vet. J., 26 (1); 20-22.

Bradley, A.J. (2002): Bovine mastitis an evolving disease. The Veterinary J., 164: 116-128.

Calvinho, L.F.; Toselli, F.G.; Weimann,W.R.; Canavesio, V.R.; Neder, V.E. and Iguzquiza, I. A. (2002): Antimicrobial Sensitivity of coagulase-positive staphylococcal strains isolated from bovine mastitis in the central dairy catchment area of Argentina. Rev. Argent. Microbiol., 34: 171-175.

Chambers, H.F. (1997): Methicillin resistance in staphylococci: Molecular and Biochemical Basis and Clinical Implications. Clin. Microbiol. Rev. 10: 781-791.

Ciftci, A; Findik, A; Onuk, E.E. and Savasan, S. (2009): Detection of methicillin resistance and slime factor production of Staphylococcus aureus in bovine mastitis. Brazilian J. of Microbiology, 40:254-261.

Deurenberg, R.H.; Vink, C.; Kalenic, S.; Friedrich, A.W.; Bruggeman, C.A. and Stobberingh, E.E. (2007): The molecular evolution of methicillin-resistant Staphylococcus aureus. Clin Microbiol Infect., 13: 222-235

Eftekhar, F. and Dadaei, T. (2011): Biofilm formation and detection of $i c a A B$ genes in clinical isolates of Methicillin resistant Staphylococcus aureus. Iranian Journal of Basic Medical Sciences, Vol. 14, No. 2: 132136. 
Eman, A. Ahmed; EL. Sangary, F.H. and Abou Zead, A.A. (2006): Bacterial and biochemical studies on mastitis of cattle in Sharkia Governorate. Assiut Vet. Med. J., 52 (109): 207-214.

Fitzpatrick, F.; Humphreys, H. and O'Gara, J.P. (2005): The genetics of staphylococcal biofilm formation-will a greater understanding of pathogenesis lead to better management of device-related infection? Clin. Microbiol. Infect. 11, 967-973.

Gianneechini, R.E.; Concha, C. and Franklin, A. (2002): Antimicrobial susceptibility of udder pathogens isolated from dairy herds in the West Littoral region of Uruguay. Acta Vet. Scand. 43: 31-41.

Haftu, R.; Taddele, H. and Gugsa, G. (2012): Prevalence, bacterial causes, and antimicrobial susceptibility profile of mastitis isolates from cows in large-scale dairy farms of Northern Ethiopia. Trop. Anim. Health Prod., 44: 1765 - 1771.

Hiramatsu, K.; Katayama, Y.; Yuzawa, H. and Ito, T. (2002): Molecular genetics of methicillin resistant Staphylococcus aureus. Int. J. Med. Microbiol., 292: 67-74.

Kateete, D.P.; $\quad$ Kabugo, U.; Baluku, H.; Nyakarahuka. L.; Kyobe, S.; Okee, M.; Najjuka, C. F. and Joloba, M.L. (2013): Prevalence and antimicrobial susceptibility patterns of bacteria from milkmen and cows with clinical mastitis in and around Kampala, Uganda. PLoS One, Volume 8, Issue 5, e63413.

Knobloch, J. K.M.; Horstkotte, M.A.; Rohde, H. and Mack, D. (2002): Evaluation of different detection methods of biofilm formation in Staph. aureus. Med. Microbiol. Immunol., 191 (2): $101-106$.

Lim, S.K.; Nam, H.M.; Jang, G.C.; Lee, H.S.; Jung, S.C. and Kim, T.S. (2013): Transmission and Persistence of Methicillin-Resistant Staphylococcus aureus in Milk, Environment, and Workers in Dairy Cattle Farms. Foodborne Pathogens and Diseases, Vol. 10, No., 8:731736.

McClure, J-A.; Conly, J.M.; Lau, V.; Elsayed, S.; Louie, T.; Hutchins, W. and Zhang, K. (2006): Novel multiplex PCR assay for detection of the staphylococcal virulence marker PantonValentine leukocidin genes and simultaneous discrimination of methicillin-susceptible from resistant staphylococci. J. Clin. Microbiol., 44 (3): 1141-1144.

Moniri, R.; Dastehgoli, K. and Akramian, A. (2007): Increasing resistant coagulase negative Staphylococci in bovine clinical mastitis. Pakistan J. of Biological Sciences, 10(15): 2465-2469.

Moon, J.S.; Lee, A.R.; Kang, H.M.; Lee, E.S.; Kim, M.N.; Paik, Y.H.; Park, Y.H., Joo, Y.S.; Koo,
H.C. (2007): Phenotypic and genetic antibiogram of methicillin-resistant staphylococci isolated from bovine mastitis in Korea. J. Dairy Sci.; 90: 1176-1185.

Nam, H.M.; Lee, A.R.; Jung, S.C.; Kim, M.N.; Jang, G.C.; Wee, S.H. and Lim, S.K. (2011): Antimicrobial susceptibility of Staphylococcus aureus and characterization of methicillinresistant Staphylococcus aureus isolated from bovine mastitis in Korea. Foodborne Pathog. Dis.; 8: 231-238.

NCCLS (2000): Performance Standards for Antimicrobial Disk Susceptibility Test. Approved Standard M2 - A7, M100 - S10. PA: National Committee for Laboratory Standards.

Quinn, P.J.; Carter, M.E.; Markey, B. and Carter, G.R. (2004): Clinical veterinary microbiology. $6^{\text {th }}$ ed., Mosby, Edinburgh, London, New York, Philadelphia, St. Louis, Sydney, Toronto.

Rasha A.Nasr; Hala M. AbuShady and Hussein, S.H. (2012): Biofilm formation and presence of icaAD gene in clinical isolates of staphylococci. The Egyptian J. of Med. Human Genetics 13:269-274.

Reddy, P.; Qi, C.; Zembower, T.; Noskin, G.A. and Bolon, M. (2007): Postpartum mastitis and community-acquired methicillin-resistant Staphylococcus aureus. Emerg. Infect. Dis., 13 (2): 298-301.

Sancak, B. (2000): S. aureus'ta metisilin direnç mekanizmalari. Mikrobiyol. Bult., 34: 381-389.

Sayed, Z.M. and Mohamed, A.E.A. (2008): Bacteriological studies on mastitis in dairy Friesian cattle in Quena Governorate. BeniSuef, Vet. Med. J., 18 (2): 19-21.

Tavakol, M.; Richard, G.M.; Otlis, C.S.; Willem, J.B.; Alex Van B. and Theo, J.G.M. (2012): Bovineassociated MRSA ST398 in the Netherland. Acta Veterinaria Scandinavica, 54:28

Vanderhaeghen, W.; Cerpentier, T.; Adriaensen, C.; Vicca, J.; Hermans, K. and Butaye, P. (2010): Methicillin-Resistant Staphylococcus aureus (MRSA) ST398 Associated with Clinical and Subclinical Mastitis in Belgian Cows. Vet. Microbiology, 144:166-171.

Vasudevan, P.; Nair, M.K.M.; Annamalai, T. and Venkitanarayanan, K.S. (2003): Phenotypic and genotyping characterization of bovine mastitis isolates of Staphylococcus aureus for biofilm formation. Vet. Microbiol., 92: 179-185.

Yazdani, R.; Oshaghi, M.; Havayi, A.; Pishva, E.; Salehi, R.; Sadeghizadeh, M. and Foroohesh, H. (2006): Detection of icaAD gene and biofilm formation in Staphylococcus aureus isolates from wound infections. Iranian J. Publ. Health 35 (2), 25-28. 


\section{دراسة بكتيريولوجية علي الميكروب المكور العنقودي المسبب لالتهاب الضرع الإكلينيكي في الماشية مع إشارة إلي المياي الميكروب العنقودي الذهبي المقاوم للميثاسيلين المبن المبني

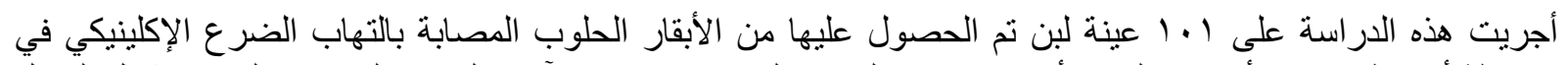

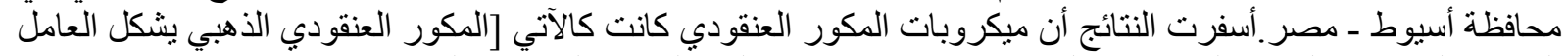

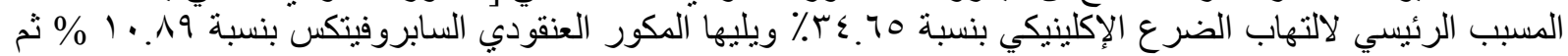

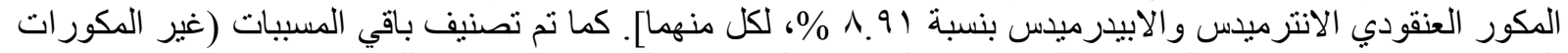

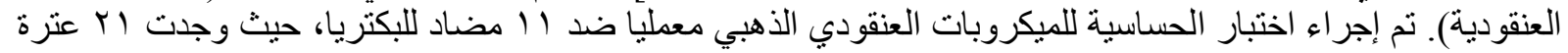

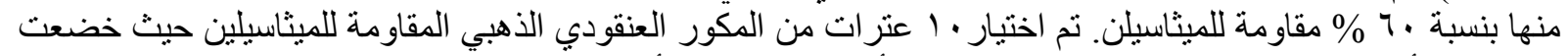

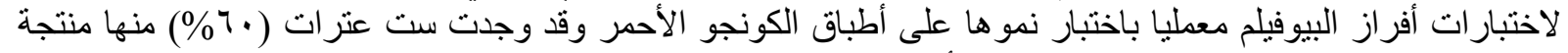

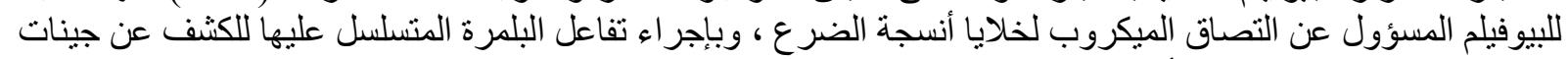
icaA, icaD, mecA

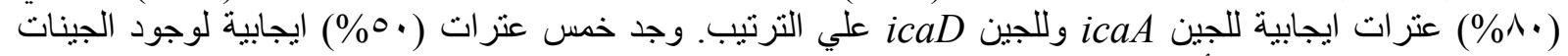
، icaA and icaD icaA and icaD mecA

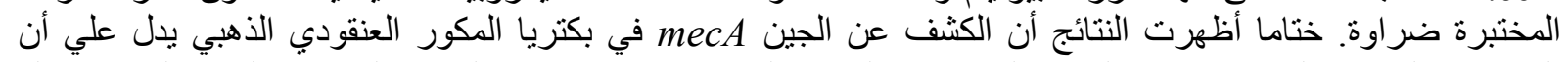

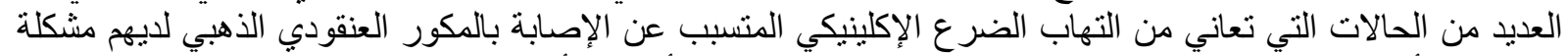
MRSA

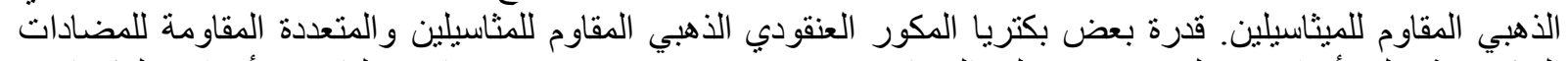

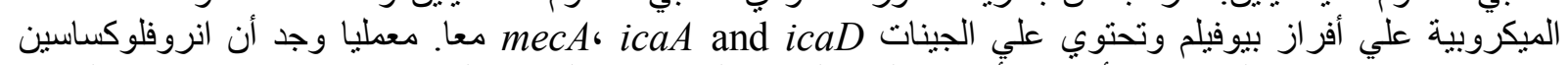

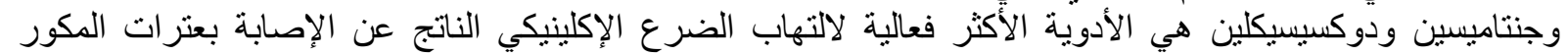
العنقودي. 